\title{
EFFECT OF THE CULTURE CONDITIONS ON THE PRODUCTION OF AN EXTRACELLULAR PROTEASE BY THERMOPHILIC BACILLUS SP AND SOME PROPERTIES OF THE ENZYMATIC ACTIVITY
}

\author{
Camila Rocha da Silva; Andréia Boechat Delatorre; Meire Lelis Leal Martins* \\ Centro de Ciências e Tecnologias Agropecuárias, Universidade Estadual do Norte Fluminense. Campos dos Goytacazes, \\ RJ, Brasil
}

Submitted: October 26, 2006; Returned to authors for corrections: January 04, 2007; Approved: March 19, 2007.

\begin{abstract}
Protease production by thermophilic Bacillus sp strain SMIA-2 cultivated in liquid cultures containing $1 \%$ maltose as a carbon source and supplemented with whey protein $(0.1 \%)$ and corn steep liquor $(0.3 \%)$ reached a maximum at $14 \mathrm{~h}$, with levels of $42 \mathrm{U} / \mathrm{mg}$ protein. The microorganism was capable of utilizing a wide range of carbon sources, but protease activity varied according the carbon source. Starch and maltose were the best carbon sources in the present study for protease secretion, while lactose and sucrose were less effective. Increasing maltose concentration in the medium until $1 \%$, improved the growth of the organism and the enzyme activity. Regarding the amounts of corn steep liquor and whey protein in the medium, the concentrations of $0.2 \%$ and $0.1 \%$ respectively, were considered the most effective for protease secretion by the organism. Studies on the protease characterization revealed that the optimum temperature of this enzyme was $70^{\circ} \mathrm{C}$. Thermostability profile indicated that the enzyme retained $80 \%$ of the original activity after $2 \mathrm{~h}$ heat treatment at $60^{\circ} \mathrm{C}$. At $70^{\circ} \mathrm{C}, 70 \%$ of the original activity was retained after $15 \mathrm{~min}$ heat treatment. The optimum $\mathrm{pH}$ of the enzyme was found to be 8.5. After incubation of crude enzyme solution at room temperature for $2 \mathrm{~h}$ at $\mathrm{pH}$ 6.0-10.0, a decreased of about $15 \%$ of its original activity at $\mathrm{pH} 8.5$ was observed. At $\mathrm{pH} 10.0$, the decrease was $24 \%$. In the presence of $1.0 \mathrm{M}$ and $5.0 \mathrm{M} \mathrm{NaCl}, 76 \%$ and $37 \%$ of protease activity was retained after $2 \mathrm{~h}$ incubating at $45^{\circ} \mathrm{C}$ respectively.
\end{abstract}

Key words: Protease, thermophilic bacterium, Bacillus sp.

\section{INTRODUCTION}

Thermostable proteases are advantageous for some applications because higher processing temperatures can be employed, with the consequences of faster reaction rates, increase in the solubility of nongaseous reactants and products, and reduced incidence of microbial contamination from mesophilic organisms (25). Thermo-stable proteases, produced from thermophilic bacteria are thus of considerable interest in a range of commercial applications $(5-9,14)$. However, thermophilic bacteria investigated to date produce proteases at levels about an order of magnitude lower than do most mesophiles, and an increase in the level of production is necessary before thermophilic proteases can become competitive as industrial enzymes (1).

Bacteria belonging to Bacillus sp. are by far the most important source of several commercial microbial enzymes $(3,6,15,22-24)$. They can be cultivated under extreme temperature and $\mathrm{pH}$ conditions giving rise to products that are in turn stable in a wide range of harsh environments (10). Most Bacillus spp. have a wide range of hydrolytic enzyme systems and are often capable of utilizing the organic matter consisting of complex mixtures typical of most wastes; moreover, with the exception of the Bacillus cereus group (which includes Bacillus

*Corresponding Author. Mailing address: Centro de Ciências e Tecnologias Agropecuárias, Universidade Estadual do Norte Fluminense. Av. Alberto Lamego, 2000. CEP 28015-620. Campos dos Goytacazes, RJ. Brazil. Tel.: (22) 2726-1460/(22) 2726-3875. E-mail: meire@uenf.br 
anthracis), they are harmless saprophytes which produce no toxins and are included in the group of organisms generally recognized as safe (GRAS) (16).

Recently, a bacterial thermophilic Bacillus sp strain SMIA2 capable of produce proteases, was isolated from a soil sample collected in Campos dos Goytacazes city, Rio de Janeiro, Brazil $(18,19)$. Phylogenetic analysis showed that this strain is a member of the Bacillus rRNA group 5. This group includes Bacillus stearothermophilus and other thermophilic Bacillus spp.

The aim of the present work was to identify the medium composition that supports protease production by Bacillus $\mathrm{sp}$ strain SMIA-2, using inexpensive materials as whey protein and corn steep liquor. Some properties of the enzyme produced were also determined.

\section{MATERIALS AND METHODS}

\section{Organism}

The bacterial strain used in this study was the thermophilic Bacillus sp strain SMIA-2, previously solated from a soil sample collected in Campos dos Goytacazes City, Rio de Janeiro, Brazil (19).

\section{Enzyme production}

The culture medium used in this work for protease production contained ( $\mathrm{g} / \mathrm{L}$ of destilled water): whey protein 1.0; corn steep liquor 3.0; maltose 10; $\mathrm{KCl} 0.3 ; \mathrm{MgSO}_{4} 0.5 ; \mathrm{K}_{2} \mathrm{HPO}_{4} 0.87 ; \mathrm{CaCl}_{2}$ $0.29 ; \mathrm{ZnO}-2.03 \times 10^{-3} ; \mathrm{FeCl}_{3} .6 \mathrm{H}_{2} \mathrm{O}-2.7 \times 10^{-2} ; \mathrm{MnCl}_{2} .4 \mathrm{H}_{2} \mathrm{O}-1.0 \times 10^{-2}$; $\mathrm{CuCl}_{2} .2 \mathrm{H}_{2} \mathrm{O}-8.5 \times 10^{-5} ; \mathrm{CoCl}_{2} .6 \mathrm{H}_{2} \mathrm{O}-2.4 \times 10^{-3} ; \mathrm{NiCl}_{3} .6 \mathrm{H}_{2} \mathrm{O}-2.5 \times 10^{-4}$ and $\mathrm{H}_{3} \mathrm{BO}_{3}-3,0 \times 10^{-4}$. The $\mathrm{pH}$ was adjusted to 6.9-7.0 with $\mathrm{NaOH}$, and this medium was sterilised by autoclaving at $121^{\circ} \mathrm{C}$ for 15 min. Maltose was sterilised separately and aseptically added to the flasks containing the liquid medium, after cooling. The above medium ( $50 \mathrm{~mL}$ in $250 \mathrm{~mL}$ Erlenmeyer flasks) was inoculated with $1 \mathrm{~mL}$ of an overnight culture and incubated at $50^{\circ} \mathrm{C}$ in a orbital shaker (Thermo Forma, Ohio, USA) operated at $150 \mathrm{rpm}$. Triplicate flasks were withdraw at regular intervals and analysed for growth $\left(\mathrm{OD} 60 \mathrm{O}_{\mathrm{nm}}\right)$ and $\mathrm{pH}$. The contents were then centrifuged at $15.500 \mathrm{~g}$ for $15 \mathrm{~min}$ at $4^{\circ} \mathrm{C}$ and the cell free supernatant was used as crude enzyme preparation.

\section{Effect of medium composition on enzyme production}

The effect of the carbon source $1 \%(\mathrm{w} / \mathrm{v})$ on enzyme secretion were investigated replacing maltose by $\mathrm{D}(+)$ galactose, lactose, sucrose, fructose, $\mathrm{D}(+)$ glucose, and starch. In addition, the concentration of maltose was varied in the culture medium from $0.05 \%$ to $2 \%$. In order to find the best concentrations of whey protein and corn steep liquor on protease production its amounts were also varied in the culture medium from $0.025 \%$ to $2.0 \%$ and $0.05 \%$ to $0.7 \%$, respectively. The effect of temperature on enzyme secretion was investigated by incubating culture flasks at $42,45,50$ and $55^{\circ} \mathrm{C}$ in a rotary incubator shaker. The effect of the medium $\mathrm{pH}$ variation on enzyme secretion was studied in a pH range of $6.5-9.5$ by adding $1 \% \mathrm{Na}_{2} \mathrm{CO}_{3}$.

\section{Enzymes assay}

Protease activity was assessed in triplicate by measuring the release of trichloroacetic-acid soluble peptides from $0.2 \%$ $(\mathrm{w} / \mathrm{v})$ azocasein in $50 \mathrm{mM} \mathrm{HEPES} / \mathrm{NaOH}$ buffer $(\mathrm{pH} 7.5)$ at $70^{\circ} \mathrm{C}$ for $10 \mathrm{~min}$. The $1-\mathrm{mL}$ reaction was terminated by the addition of $0.5 \mathrm{~mL}$ of $15 \%$ trichloroacetic acid and then centrifuged at 20.600 $\mathrm{g}$ for $10 \mathrm{~min}$, after cooling. One enzyme activity unit (U) was defined as the amount of enzyme required to produce an increase in absorbance at $420 \mathrm{~nm}$ equal to 0.1 in 60 minutes (12).

Protein was measured by the method of the Lowry, as modified by Petterson $(20,21)$.

\section{Effect of the $\mathrm{pH}$ on protease activity and stability}

The $\mathrm{pH}$ optimum was determined with azocasein $1 \%(\mathrm{w} / \mathrm{v})$ as substrate, dissolved in different buffers (citrate phosphate, $\mathrm{pH}$ 5-6, sodium phosphate, $\mathrm{pH} 7.0$, Tris- $\mathrm{HCl}, \mathrm{pH} 8.0$ and glycine $\mathrm{NaOH}, \mathrm{pH} 9-10)$. The effect of $\mathrm{pH}$ on enzyme stability was determined by pre-incubating the crude enzyme preparation without substrate at different $\mathrm{pH}$ values (6.0-10.0) for $2 \mathrm{~h}$ at room temperature, and measuring the residual activity at $70^{\circ} \mathrm{C}$.

\section{Effect of temperature on the proteolytic activity and stability}

The effect of temperature on the enzyme activity was determined by performing the standard assay procedure at $\mathrm{pH}$ 7.5 within a temperature range of $40-100^{\circ} \mathrm{C}$. Thermostability was determined by incubation of crude enzyme preparating at temperatures ranging from $40-100^{\circ} \mathrm{C}$ for $2 \mathrm{~h}$ in a constanttemperature water bath. After treatment the residual proteolytic activity was assayed.

\section{Stability of protease in sodium chloride}

Crude enzyme preparation was pre-incubated in phosphate buffer $(0.05 \mathrm{M}, \mathrm{pH} 8.5)$ containing various $\mathrm{NaCl}$ concentrations $(0.5-5.0 \mathrm{M})$, at $45^{\circ} \mathrm{C}$ for 1 and $2 \mathrm{~h}$. In each case the activity of the enzyme was measured in the same way as mentioned earlier.

\section{RESULTS AND DISCUSSION}

\section{Culture conditions for enzyme production}

Fig. 1 reports the time-course of protease production by Bacillus sp. SMI-2 grown in liquid medium containing maltose $(1 \%)$ as a carbon source and supplemented with whey protein $(0.1 \%)$ and corn steep liquor $(0.3 \%)$ in $250 \mathrm{~mL}$ Erlenmeyer flask. Protease production reached a maximum at $14 \mathrm{~h}$, with levels of $42 \mathrm{U} / \mathrm{mg}$ protein. The $\mathrm{pH}$ of the medium initially dropped as cells started to grow, but as soon as enzyme production was initiated, the $\mathrm{pH}$ started to rise. This may indicate that some consumption of organic nitrogen in (4). The end of enzyme production was signalled by a slight decrease of the $\mathrm{pH}$ 


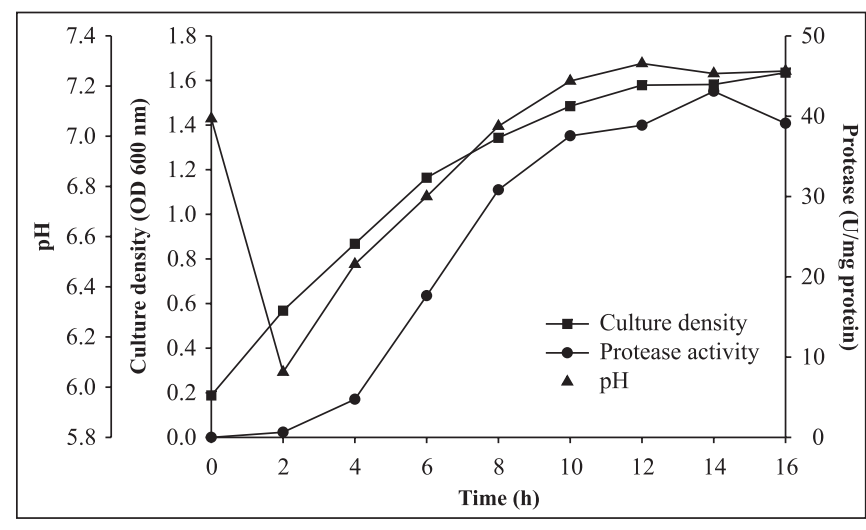

Figure1. Protease production as a function of cultivation time by Bacillus sp grown on maltose (1.0\%), whey protein $(0.1 \%)$ and corn steep liquor $(0.3 \%)$ in shake flasks at initial $\mathrm{pH} 7.5$ and at $50^{\circ} \mathrm{C}$.

variation. Thus the $\mathrm{pH}$ profile provides a useful means of monitoring the production process.

Bacillus sp SMIA-2 was capable of using a wide range of carbon sources, but production of protease varied according each carbon source (Table 1). Starch and maltose were the best carbon sources in the present study for protease secretion while lactose and sucrose were less effective. Moderate to good amount of protease activity was produced in the presence of fructose, galactose, and glucose. In a similar study Basalp et al. (2) showed that although glucose could not support for maximum protease production in Bacillus subtilis, yet it emerged as a better substrate than maltose, starch and galactose. On the other hand, Johnvesly and Nailk (13) reported that culturing Bacillus sp. JB-99 in glucose 1\% (w/v) the protease synthesis was completely repressed.

Table 1. Effect the carbon source on Bacillus sp growth and protease activity by. The culture density and extracellular protease activity were determined during $16 \mathrm{~h}$ incubation at $50^{\circ} \mathrm{C}$ and at initial $\mathrm{pH} 7.0$.

\begin{tabular}{ccc}
\hline Carbon source & $\begin{array}{c}\text { Culture density } \\
\left(\mathrm{OD}_{600 \mathrm{~m}}\right)\end{array}$ & $\begin{array}{c}\text { Maximum } \\
\text { enzyme activity } \\
\text { (U/mg protein) }\end{array}$ \\
\hline Starch & 1.58 & 36.4 \\
Frutose & 1.33 & 25.0 \\
Galactose & 1.52 & 24.3 \\
Glucose & 1.22 & 22.2 \\
Lactose & 1.39 & 15.5 \\
Maltose & 1.55 & 35.8 \\
Sucrose & 1.08 & 12.6 \\
\hline
\end{tabular}

The effect of maltose on protease production was studied (Fig. 2). Increasing maltose concentration in the medium to $1 \%$, improved the growth of the organism and the protease production. At higher maltose concentrations, enzyme production was comparatively lower.

In order to find the optimum level of whey protein and corn steep liquor to protease production, its concentrations were varied in the culture medium. The activity of the enzyme increased between $0.05 \%$ and $0.2 \%$ corn steep liquor concentration and then fell beyond this point (Fig. 3a). In Bacillus subtilis ATCC 14416 the best concentration of corn steep liquor in the medium to protease production was $0.5 \%$ (4). Regarding to whey protein, concentrations between $0.1 \%$ and $0.15 \%$ were optimum for maximum protease activity (Fig. 4 ). Thus, the medium containing $0.2 \%$ corn steep liquor and $0.1 \%$ whey protein was considered the most effective for protease production by Bacillus sp strain SMIA-2.

Protease activity varied with initial $\mathrm{pH}$ of the culture medium (Table 2). The highest levels of protease activity were detected in cultures grown at $\mathrm{pH} 7.5$ - 8.0. Although the growth was highest at $\mathrm{pH} 9.5$ the amount of protease was almost a half of that observed at $\mathrm{pH} 7.5-8.0$. The protease secretion was maximum at $50^{\circ} \mathrm{C}$ (Table 3 ) and was less at high $\left(55^{\circ} \mathrm{C}\right)$ and low $\left(42^{\circ} \mathrm{C}\right)$ temperatures.

\section{Effect of $\mathrm{pH}$ on protease activity and stability}

A pH range between 6.0 and 10.0 was used to study the effect of $\mathrm{pH}$ on protease activity (Fig. 4). Optimum $\mathrm{pH}$ was found to be 8.5 . The protease activity at $\mathrm{pH} 6.0$ and $\mathrm{pH} 10.0$ were $65 \%$ and $83 \%$ of that at $\mathrm{pH} 8.5$, respectively. After incubation of crude enzyme solution at room temperature for 2

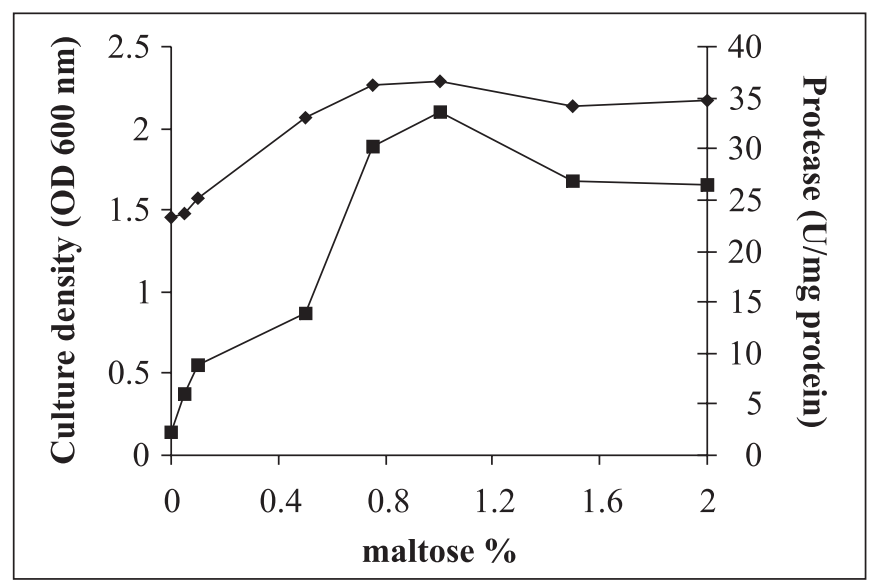

Figure 2. Effect of maltose concentration on growth ( $\boldsymbol{\square})$ and protease activity $(\checkmark)$ of Bacillus sp cultivated in a liquid medium containing whey protein $(0.1 \%)$ and corn steep liquor $(0.3 \%)$ in shake flasks at initial $\mathrm{pH} 7.5$ and at $50^{\circ} \mathrm{C}$. 


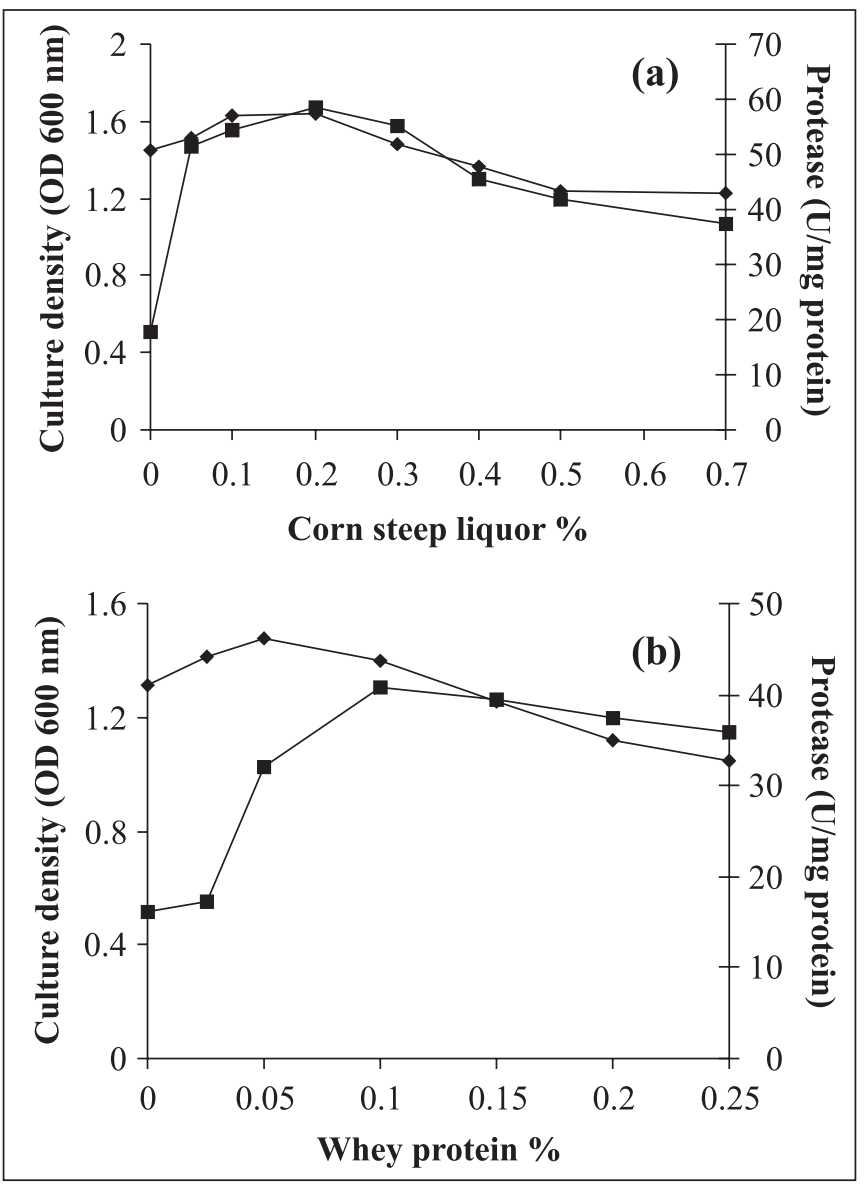

Figure 3. Effect of corn steep liquor concentration (a) and whey protein concentration (b) on growth $(\diamond)$ and protease activity (ם) of Bacillus sp cultivated in a liquid medium containing maltose $(1.0 \%)$ in shake flasks at initial $\mathrm{pH} 7.5$ and at $50^{\circ} \mathrm{C}$.

$\mathrm{h}$ at $\mathrm{pH} 6.0-10.0$, a decreased of about $15 \%$ of its original activity at pH 8.5 was observed. At pH 10.0, the decrease was $24 \%$. Thus, protease of Bacillus sp strain SMIA-2 seems to be active in very broad $\mathrm{pH}$ range.

\section{Effect of temperature on protease activity and stability}

Protease activity was assayed at different temperatures ranging from $40^{\circ} \mathrm{C}-100^{\circ} \mathrm{C}$ at a constant $\mathrm{pH}$ of 8.5 (Fig. 5a). Enzyme activity increased with temperature within the range of $40^{\circ} \mathrm{C}$ to $70^{\circ} \mathrm{C}$. A reduction in enzyme activity was observed at values above $70^{\circ} \mathrm{C}$. The optimum temperature of this protease was $70^{\circ} \mathrm{C}$, which was higher or similar to that described for other Bacillus proteases $(1,11,13,17)$. The thermostability of the protease was examined by measuring the remaining activities at $70^{\circ} \mathrm{C}$, after incubation of the enzyme without substrate at various temperatures between 40 and $100^{\circ} \mathrm{C}$ for $2 \mathrm{~h}$ (Fig. 5a). Thermostability profile indicated that the enzyme

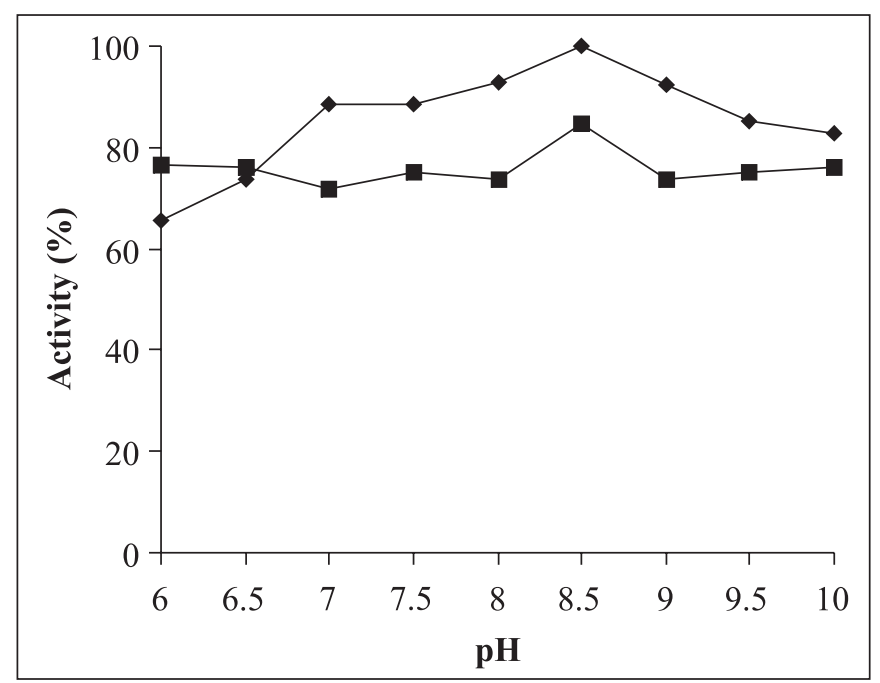

Figure 4. Optimum $\mathrm{pH}(\bullet)$ and stability $(\boldsymbol{\square})$ of protease activity produced by Bacillus sp grown at $50^{\circ} \mathrm{C}$ for $14 \mathrm{~h}$. Relative activity is expressed as a percentage of the maximum (100\% of enzyme activity $=35.8 \mathrm{U} / \mathrm{mg}$ protein).

Table 2. Effect of initial $\mathrm{pH}$ on growth and protease activity by Bacillus sp cultivated in a liquid medium containing maltose $(1.0 \%)$, whey protein $(0.1 \%)$ and corn steep liquor $(0.2 \%)$ in shake flasks during $16 \mathrm{~h}$ at $50^{\circ} \mathrm{C}$.

\begin{tabular}{ccc}
\hline Initial pH & $\begin{array}{c}\text { Culture density } \\
\left(\mathrm{OD}_{600 \mathrm{~nm}}\right)\end{array}$ & $\begin{array}{c}\text { Maximum } \\
\text { protease activity } \\
\text { (U/mg protein) }\end{array}$ \\
\hline 6.5 & 0.93 & 16.7 \\
7.0 & 1.11 & 37.2 \\
7.5 & 1.22 & 49.1 \\
8.0 & 1.34 & 48.0 \\
8.5 & 1.69 & 40.2 \\
9.0 & 1.91 & 39.7 \\
9.5 & 1.94 & 25.9 \\
\hline
\end{tabular}

Table 3. Effect of temperature on growth and protease activity by Bacillus sp cultivated in a liquid medium containing maltose $(1.0 \%)$, whey protein $(0.1 \%)$ and corn steep liquor $(0.2 \%)$ in shake flasks at initial $\mathrm{pH} 7.5$ during $16 \mathrm{~h}$.

\begin{tabular}{ccc}
\hline Temperature ${ }^{\circ} \mathrm{C}$ & $\begin{array}{c}\text { Culture density } \\
\left(\mathrm{OD}_{600 \mathrm{~nm}}\right)\end{array}$ & $\begin{array}{c}\text { Maximum } \\
\text { protease activity } \\
(\mathrm{U} / \mathrm{mg} \text { protein })\end{array}$ \\
\hline 42 & 1.10 & 37.2 \\
45 & 1.42 & 40.1 \\
50 & 1.92 & 59.2 \\
55 & 1.12 & 18.3 \\
\hline
\end{tabular}




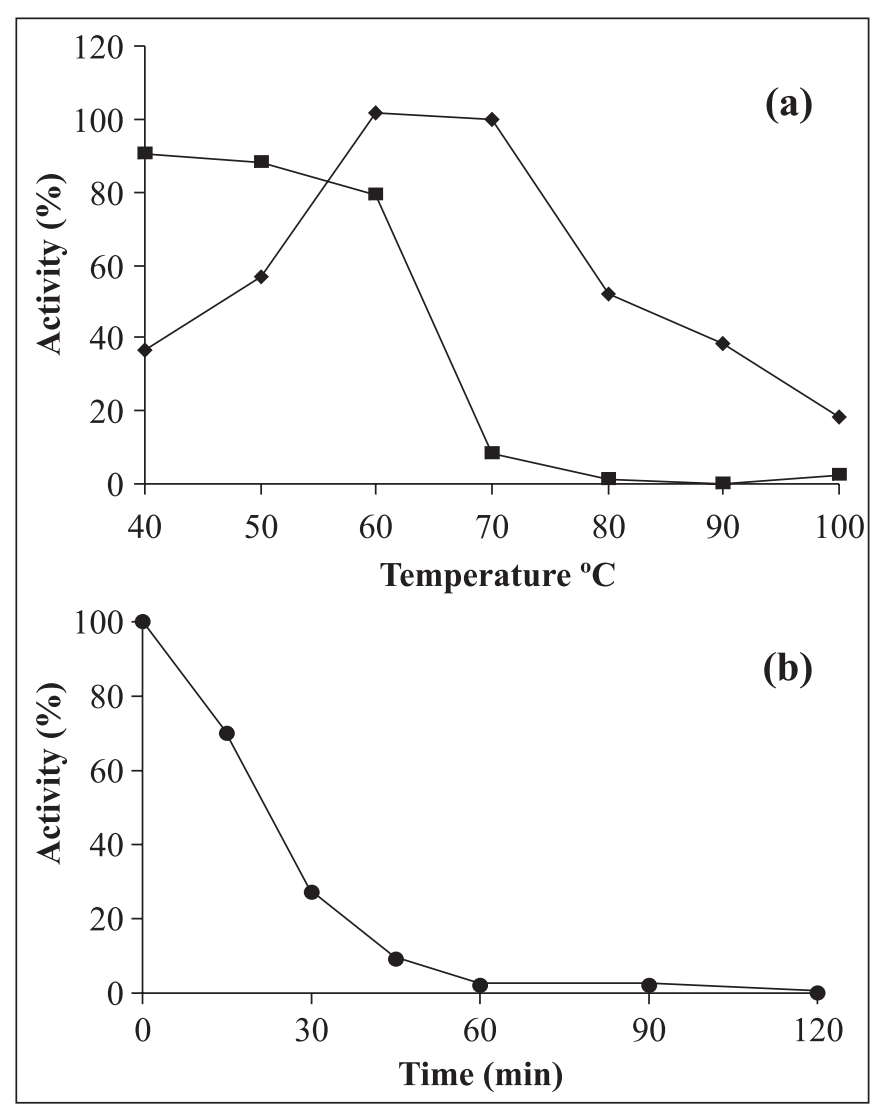

Figure 5. Optimum temperature $(\diamond)$ and stability ( $\mathbf{\square}$ ) of protease activity produced by Bacillus sp grown at $50^{\circ} \mathrm{C}$ for $14 \mathrm{~h}$ (a). Thermostability of protease at $70^{\circ} \mathrm{C}$ (b). Relative activity is expressed as a percentage of the maximum (100\% of enzyme activity $=43.3 \mathrm{U} / \mathrm{mg}$ protein).

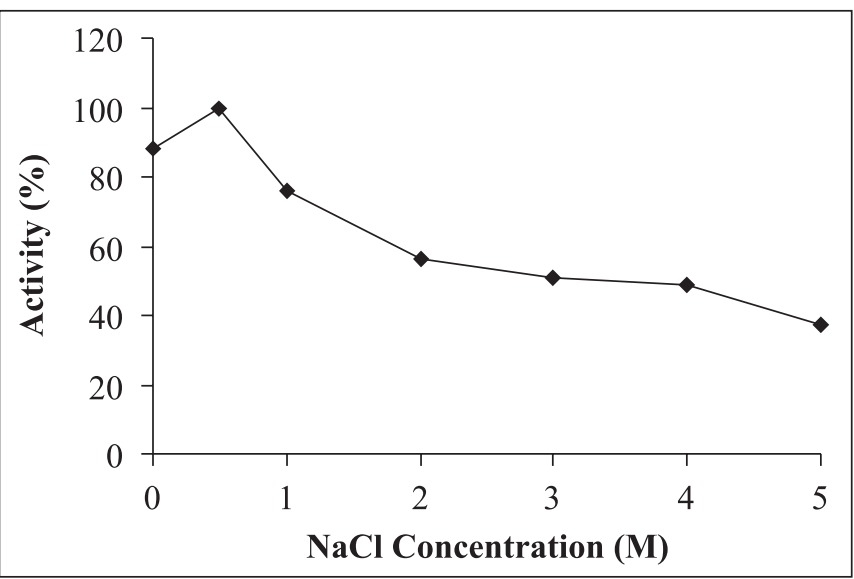

Figure 6. Effect of $\mathrm{NaCl}$ concentration on protease produced by Bacillus sp. grown at $50^{\circ} \mathrm{C}$ for $14 \mathrm{~h}$. Relative activity is expressed as a percentage of the maximum (100\% of the enzyme activity $=41 \mathrm{U} / \mathrm{mg}$ protein). retained $80 \%$ of the original activity after $2 \mathrm{~h}$ heat treatment at $60^{\circ} \mathrm{C}$. At $70^{\circ} \mathrm{C}, 70 \%$ of the original activity was retained after 15 min heat treatment (Fig. 5b). The protease from Bacillus sp JB99 retained $63 \%$ and $25 \%$ of original activity after $1 \mathrm{~h}$ heat treatment at $70^{\circ} \mathrm{C}$ and $80^{\circ} \mathrm{C}(13)$. In addition, the protease from Bacillus licheniformis SMI 4.C.1. retained $60 \%$ of original activity after $30 \mathrm{~min}$ heat treatment at $70^{\circ} \mathrm{C}(17)$.

\section{Protease stability in sodium chloride}

In the presence of $1.0 \mathrm{M}$ and $5.0 \mathrm{M} \mathrm{NaCl}, 76 \%$ and $37 \%$ of protease activity respectively, was retained after $2 \mathrm{~h}$ incubating at $45^{\circ} \mathrm{C}$. Bacillus sp. JB-99 retained $84 \%$ and $41 \%$ of protease activity when incubating at $45^{\circ} \mathrm{C}$, in the presence of $1.0 \mathrm{M}$ and $5 \mathrm{M}$ for $2 \mathrm{~h}$, respectively.

Collectively, these results may justify the suitability of the Bacillus sp SMIA-2 for commercial production of protease, using inexpensive materials.

\section{ACKNOWLEDGMENTS}

The authors thank the FAPERJ (Fundação Carlos Chaga Filho de Amparo à Pesquisa do Estado do Rio de Janeiro) for financial support.

\section{RESUMO}

Efeito das condições de cultivo sobre a produção de proteases extracelulares pelo termofílico Bacillus sp e algumas propriedades da atividade enzimática

A produção de proteases pelo termofílico Bacillus sp cepa SMIA-2 cultivado em culturas líquidas contendo maltose (1\%) e suplementada com proteínas de soro $(0,1 \%)$ e água de maceração de milho $(0,3 \%)$ alcançou o máximo em 14 h, com níveis de $42 \mathrm{U} / \mathrm{mg}$ proteína. O microrganismo foi capaz de utilizar várias fontes de carbono, mas a atividade da protease variou com cada fonte. Amido e maltose foram as melhores fontes para a secreção da protease, enquanto lactose e sacarose não foram muito efetivas. $\mathrm{O}$ aumento da concentração de maltose no meio de cultura até $1 \%$ melhorou o crescimento do organismo e a atividade da enzima. Em relação à concentração de proteínas do soro e da água de maceração de milho no meio de cultura, $0,1 \%$ e $0,2 \%$ respectivamente, foram as mais efetivas para a secreção da enzima pelo organismo. Estudos sobre a caracterização da protease revelaram que a temperatura ótima desta enzima foi $70^{\circ} \mathrm{C}$. Em relação a termoestabilidade da enzima, a protease manteve $80 \%$ de sua atividade original após $2 \mathrm{~h}$ de tratamento a $60^{\circ} \mathrm{C} . \mathrm{A} 70^{\circ} \mathrm{C}, 70 \%$ de sua atividade original foi mantida após 15 min. O pH ótimo para atividade da enzima foi 8,5. Após a incubação da solução enzimática bruta a pH 6,0-10.0 por $2 \mathrm{~h}$ a temperatura ambiente, foi observado um decréscimo de em torno de $15 \%$ da sua atividade original a pH 8,5. ApH 10,0 o decréscimo 
na atividade foi de $24 \%$. Na presença de $1.0 \mathrm{M}$ e $5.0 \mathrm{M} \mathrm{NaCl}$, $76 \%$ e $37 \%$ da atividade da protease foi mantida após $2 \mathrm{~h}$ de incubação a $45^{\circ} \mathrm{C}$ respectivamente.

Palavras-chaves: Protease, bactéria termofílica, Bacillus sp.

\section{REFERENCES}

1. Banerjee, U.C.; Sani, R.K.; Azmi, W.; Soni, R. (1999). Thermostable alkaline protease from Bacillus brevis and its characterization as a laundry detergent additive. Process Biochem., 35, 213-219.

2. Basalp, A.; Ozeengiz, G.; Alaeddinglin, N.G. (1992). Changes in patterns of alkaline serine protease and Bacilysin formation caused by common effectors of sporulation in Bacillus subtilis 168. Curr Microbiol., 24, 129-135.

3. Beg, Q.K.; Gupta, R. (2003). Purification and characterization of an oxidation-stable, thiol-dependent serine alkaline protease from Bacillus mojavensis. Enzyme Microbial. Technol., 32, 294-304.

4. Chu, I.-M.; Lee, C.; Li, T-S. (1992). Production and Degradation of Alkaline Protease in Batch Cultures of Bacillus subtilis ATCC 14416. Enzyme Microbial. Technol., 14, 755-761.

5. Cowan D.A.; Daniel, R.M.; Morgan, H.W. (1985). Thermophilic proteases: properties and potencial applications. Trends in Biotechnol., 3, 68-72.

6. Ferrero, M.A.; Castro, G.R.; Abate, C.M.; Baigori, M.D.; Singeriz, F. (1996). Thermostable alkaline proteases of Bacillus licheniformis MIR 29: isolation, production and characterization. Appl. Microbiol. Biotechnol., 45, 327-332.

7. Gupta, R.; Gupta, K.; Saxena, R.K.; Khan, S. (1999). Bleach-stable, alkaline protease from Bacillus sp. Biotechnol. Lett., 21, 135-138.

8. Gupta, R.; Beg, Q.K.; Lorenz, P. (2002). Bacterial alkaline proteases: molecular approaches and industrial applications. Appl. Microbiol. Biotechnol., 59, 15-32.

9. Haki, G.D.; Rakshit, S.K. (2003). Developments in industrially important thermostable enzymes: a review. Biores. Tecnol., 89, 1734.

10. Han, X.Q., Damodaran, S. (1997). Isolation, identification and fermentation of a Bacillus species producing a detergent-stable endopeptidase. J. Agric. Food Chem., 45, 4191-4195.

11. Horikoshi, K. Enzymes of alkalophilies. (1990). In: Microbial Enzyme and Biotechnology, 2 ${ }^{\text {nd }}, 275-94$.
12. Janssen, P.H.; Peek, K.; Morgan, H.W. (1994). Effect of culture conditions on the production of a extracellular proteinase by Thermus sp. Rt41A. Appl. Microbiol. Biotechnol., 41, 400-406.

13. Johnvesly, B.; Naik, G.R. (2001). Studies on production of thermostable alkaline protease from thermophilic and alkaliphilic Bacillus sp. JB-99 in a chemically defined medium. Process Biochem., 37, 139-144.

14. Kim, Y.; Bae, J.; Oh, B.; Lee, W.; Choi, J. (2002). Enhanced of proteolytic enzyme activity excreted from Bacillus stearothermophilus for a thermophilic aerobic digestion process. Biores. Technol., 82, 157-164.

15. Kumar, C.G.; Tiwari, M.P.; Jany, K.D. (1999). Novel alkaline serine proteases from alkalophilic Bacillus spp.: Purification and some properties. Process Biochem., 34, 441-449.

16. Mahmood, A.U.; Greenman, J.; Scragg, A.H. (1998). Orange and potato pell extracts: Analysis and use as Bacillus substrates for the production of extracellular enzymes in continuous culture. Enzyme Microbial. Technol., 22, 130-137.

17. Manachini, P.L.; Fortina, M.G.; Parini, C. (1988). Thermostable alkaline protease produced by Bacillus thermoruber a new species of Bacillus. Appl. Microbiol., 28, 409-413.

18. Nascimento, W.C.A.; Martins, M.L.L. (2004). Production and properties of an extracellular protease from thermophilic Bacillus sp. Braz. J. Microbiol., 35, 91-96.

19. Nunes, A.S.; Martins, M.L.L. (2001). Isolation, properties and kinetics of growth of a thermophilic Bacillus. Braz. J. Microbiol., 32, 271-275.

20. Peterson, G.L. (1977). A simplification of the protein assay method of Lowry et al. which is more generally applicable. Analytical Biochem., 83, 346-356.

21. Rao, M.B.; Tanksale, A.M.; Ghatge, M.S. (1998). Molecular and biotechnology aspects of microbial proteases. Microbiol. Mol. Biol. Ver., 62, 597-635.

22. Singh, J.; Batra, N.; Sobti, C.R. (2001). Serine alkaline protease from a newly isolated Bacillus sp. SSR1. Process Biochem., 36, 781-785.

23. Sinha, N.; Satyanarayana, T. (1991). Alkaline protease by thermophilic Bacillus licheniformis. Indian J. Microbiol., 31, 425-430.

24. Sookkheo, B.; Sinchaikul, S.; Phutrakul, S.; Chen, S.T. (2000). Purification and characterization of the highly thermostable proteases from Bacillus stearothermophilus TLS33. Prot. Exp. Pur., 20, 142-151.

25. Ward, O.P. Proteolytic enzymes. (1985). In: M. Moo-Young Editor, Comprehensive Biotechnol., 3, 789-818. 